\title{
Effects of withholding fertiliser on pasture production and phosphate cycling in hill country
}

\section{J.S. Rowarth' and A.G. Gillingham ${ }^{2}$}

'DSIR Grasslands, Lincoln

${ }^{2}$ MAFTech Pastoral Research Centre, Flock House, Bulls

ABSTRACT A large-scale phosphate (P) fertiliser grazing trial was carried out at Whatawhata Research Centre between 1980 and 1984. The effect of 5 fertiliser rates $(10,2030,50$ or $100 \mathrm{~kg} \mathrm{P} / \mathrm{ha})$ on pasture production, plant $\mathrm{P}$ uptake, dung $\mathrm{P}$ distribution, dung decomposition and Olsen $\mathrm{P}$ concentration were monitored on 4 slope groups (campsites, 0-10"; easy, 1 I-20"; moderate, 21-30" and steep, 31" +). Soils collected from each slope and fertiliser treatment were used in a pot trial to investigate the size of the plantavailable $\mathrm{P}$ pool. Results can be used to interpret data from field trials where fertiliser has been withheld. Initially, pasture production or Olsen $\mathrm{P}$ will change little because the most productive areas of the paddock receive large amounts of dung $\mathrm{P}$ which buffer the effect of fertiliser withdrawal. On these areas $\mathrm{P}$ is cycled more rapidly than on steep slopes, further buffering the system against $\mathrm{P}$ deficiency. Small changes in Olsen $\mathrm{P}$ do not reflect the more rapid changes in inorganic $\mathrm{P}$ or plant-available P. As inorganic P becomes depleted, plant $\mathrm{P}$ uptake decreases. The associated decrease in dung $\mathrm{P}$ return and the slower rate of dung decomposition contribute to a slowing of the $\mathrm{P}$ cycle. The net effect is less feed and slower regrowth after grazing. Recovering from this state will require not only $\mathrm{P}$ fertiliser but also time for high producing pasture species to regenerate.

Keywords phosphate cycling, topdressing, fertiliser, pasture production, hill country, dung

\section{INTRODUCTION}

Fears that hill country farm production would crash because of the withdrawal of fertiliser inputs have largely been dispelled. In fact only small, if any, decreases have been noticed (O'Connor et al. 1985; Gillingham et al. 1989; Lambert et al. 1989; O'Connor et al. 1989). In consequence, many farmers are questioning why they have applied fertiliser in the past.

An investigation was carried out at Whatawhata Research Centre to examine aspects of the $\mathrm{P}$ cycle in hill country pasture. Information from the investigation can be used in an attempt to explain why the decline in production is slow in the initial years of withholding fertiliser.

\section{METHODS}

The trial site was at Whatawhata Research Centre, latitude 37" $48^{\prime}$ s, altitude $220 \mathrm{~m}$ a.s.l., $22 \mathrm{~km}$ west of Hamilton in the North Island of New Zealand. The trial was located in moderately steep, summerdry hill country on what was predominantly a Kaawa hill soil (Bruce 1976), a northern yellowbrown earth (Typic Haplohumult) derived from argillaceous greywacke. It comprised 20 paddocks (0.243-I ,223 ha) topdressed annually at 5 different rates of P: $10,20,30,50$ or $100 \mathrm{~kg} / \mathrm{ha}$. Inputs and outputs of $\mathrm{P}$ were monitored on 4 slope groups (campsites, 0-10 ; easy, 1 1-20"; moderate, 21-30" and steep, $31^{\circ}+$ ) in 5 of the paddocks; easy and steep slopes were monitored in all paddocks.

Pasture production, the concentration of $\mathrm{P}$ in herbage (Twine \& Williams 1971), dung P distribution, Olsen P (Olsen et al. 1954), and inorganic P in soil (Walker \& Adams 1958) were monitored on each slope group. Dung dry matter distribution after each grazing was measured by a calibrated eye-assessment (Rowarth 1987). Concentration of $\mathrm{P}$ in dung was analysed by a modification of the method of Walker \& Adams (1958).

Dung decomposition was measured on campsites, easy slopes and steep slopes in winter and summer. Freshly voided dung samples were sealed in mesh bags and pegged onto the trial site. Bags were collected after each major rainfall, contents were weighed, and dung $P$ determined.

Phosphorus uptake by ryegrass in a pot trial was used to measure the amount of plant-available $\mathrm{P}$ in soils from three slopes (campsites, easy and steep) at two depths (O-30 and 30-70 mm). Ten harvests were taken at approximately 5-week intervals. Olsen and inorganic $\mathrm{P}$ were measured before and after the trial.

\section{RESULTS AND DISCUSSION}

Pasture production decreased with increasing land slope (Figure 1), campsites and easy slopes producing nearly $70 \%$ of the total production within a paddock. On moderate and steep slopes, yields increased with increasing rate of fertiliser $\mathrm{P}$ to a maximum value (which was less than that of easy slopes and campsites), indicating that some factor other than $\mathrm{P}$ was limiting growth. On campsites and easy slopes, high-fertility species were able to respond to fertiliser inputs because moisture and nutrient limitations were reduced. In fact no 
maximum production was measured, even at excessively high rates of $\mathrm{P}$ addition $(100 \mathrm{~kg} / \mathrm{ha})$ and with associated Olsen $\mathrm{P}$ concentrations exceeding 30. Thus any effect of withholding fertiliser has different starting points on different slopes, and different scope for decreasing pasture production.

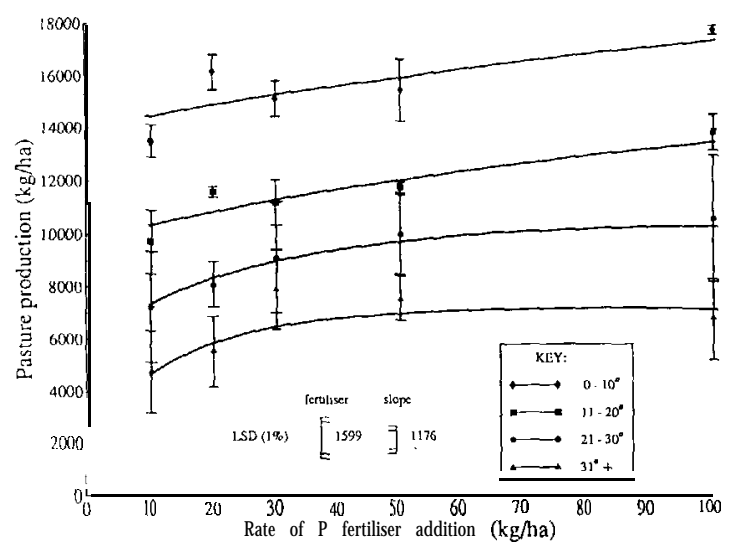

Figure 1 Effect of $\mathrm{P}$ fertiliser addition and slope on average annual pasture production $(\mathrm{kg} / \mathrm{ha})$. Data presented are the averages of 3 years measurements from the 5 intensively sampled paddocks.

More dung $\mathrm{P}$ was deposited on campsites $(60 \%$ of the total within a paddock) than steep slopes (5\%) (Table 1). On campsites more $\mathrm{P}$ was deposited in dung than was taken up by pasture (Table 1), indicating that $\mathrm{P}$ was being transferred to campsites. Furthermore, on campsites and during winter and spring, dung decomposition occurred much more rapidly than on steep slopes and during summer and autumn (Figure 2). Better soil moisture status (Gillingham \& Bircham 1985), greater microand macro-fauna activity (particularly that of earthworms, which play a major role in dung decomposition) (White 1960), and greater pasture growth (providing a protective environment and decreasing dung moisture loss) all contribute to the higher decomposition rate on campsites than steep slopes and in winter/spring than summer/autumn The higher rate is also a result of the fact that dung deposited in winter has a lower dry matter content and higher $\mathrm{P}$ concentration (e.g., $28 \%$ and $1.2 \%$ respectively) than that deposited in summer $(35 \%$ and $0.6 \%$, respectively), and is therefore more susceptible to breakdown (Rowarth et al. 1985, 1988).

Table I The effect of slope on dung $\mathrm{P}$ deposition

\begin{tabular}{lrc}
\hline Slope & $\begin{array}{r}\text { \% of total dung P } \\
\text { deposited in paddock }\end{array}$ & $\begin{array}{c}\text { \% of total plant P uptake } \\
\text { supplied by dung P }\end{array}$ \\
\hline O-10 & $\mathbf{6 0}$ & $\mathbf{1 3 8}$ \\
$11-20$ & 23 & $\mathbf{8 4}$ \\
$21-30$ & 12 & $\mathbf{5 5}$ \\
$31^{\circ}+$ & $\mathbf{5}$ & $\mathbf{2 9}$ \\
\hline
\end{tabular}

Olsen $\mathrm{P}$ concentration increased most at high rates of fertiliser $\mathrm{P}$ and on steep slopes (Figure 3 ). That is, in those areas where more fertiliser $\mathrm{P}$ was applied than was needed for maximum growth, it could be measured as an increase in Olsen P.

In the pot trial, herbage $\mathrm{P}$ uptake was highly correlated with both Olsen $\mathrm{P}\left(\mathrm{r}=0.96^{* *}\right)$ and inorganic $\mathrm{P}(\mathrm{r}=0.91$ "“). Olsen $\mathrm{P}$ decreased considerably where initial values had been high $(>$ 60) and changed little where initial values had been low $(<15)$. At a given Olsen $\mathrm{P}$ concentration approximately $40 \%$ more $\mathrm{P}$ was available in the 0 $30 \mathrm{~mm}$ than the $30-70 \mathrm{~mm}$ depth (Figure 4). As moisture and nutrients other than $\mathrm{P}$ did not limit plant growth in the trial, these results suggest that at a given Olsen test, plant availability is affected by changes in other factors such as organic matter, structure, texture, P-sorption capacity and other soil characteristics inherent with changes in depth.

Plant uptake of $\mathrm{P}$ was proportional to the depletion of the inorganic $\mathrm{P}$ pool during the trial (plant $\mathrm{P}$ uptake $=0.96$ change in inorganic $\mathrm{P}+$ $16.9 ; r=0.91$ "'). Change in Olsen $\mathrm{P}$ was related to change in inorganic $\mathrm{P}$ (change in Olsen $\mathrm{P}=0.19$ change in inorganic $\left.\mathrm{P}+1.51 ; \mathrm{r}=0.88^{* *}\right)$.

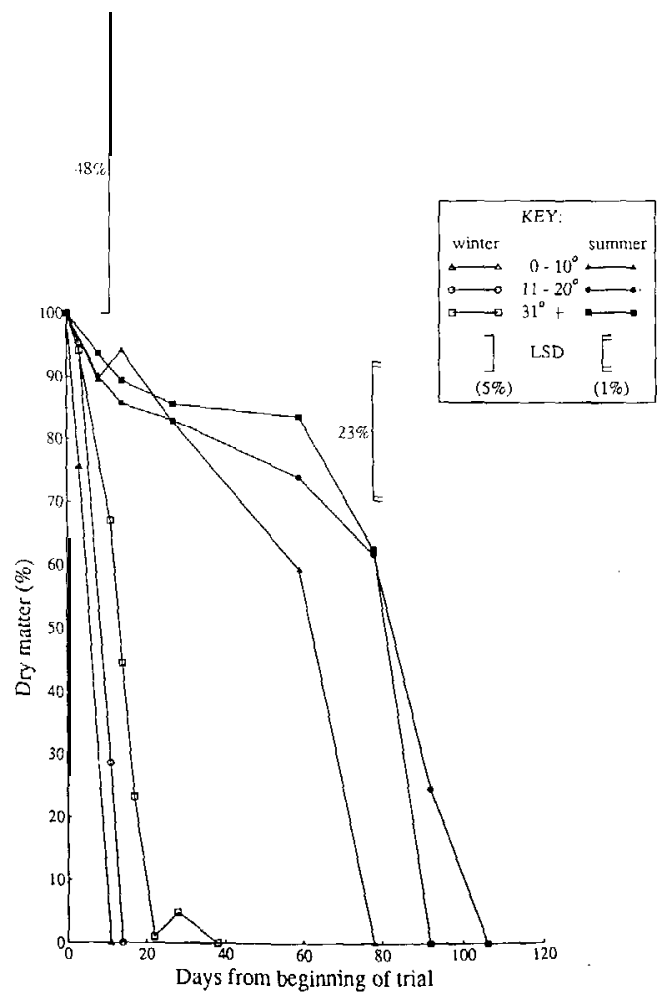

Figure 2 Change (\%) in dry matter of faecal pads as a function of time under winter and summer conditions. Values are the means of 4 and 6 samples for the winter and summer trial respectively. 
The present results can be used to interpret data from field trials where fertiliser has been withheld. Initially, pasture production or Olsen $\mathrm{P}$ changes little because the most productive areas of the paddock (campsites and easy slopes) receive large amounts of dung $\mathrm{P}(138 \%$ and $84 \%$ of plant $\mathrm{P}$ requirements, respectively) which buffer the effect of fertiliser withdrawal. Furthermore, the dung $\mathrm{P}$ is deposited at every grazing and so forms a continuous supply of extra $\mathrm{P}$ which is released rapidly when plants are growing rapidly and slowly when plant growth is restricted.

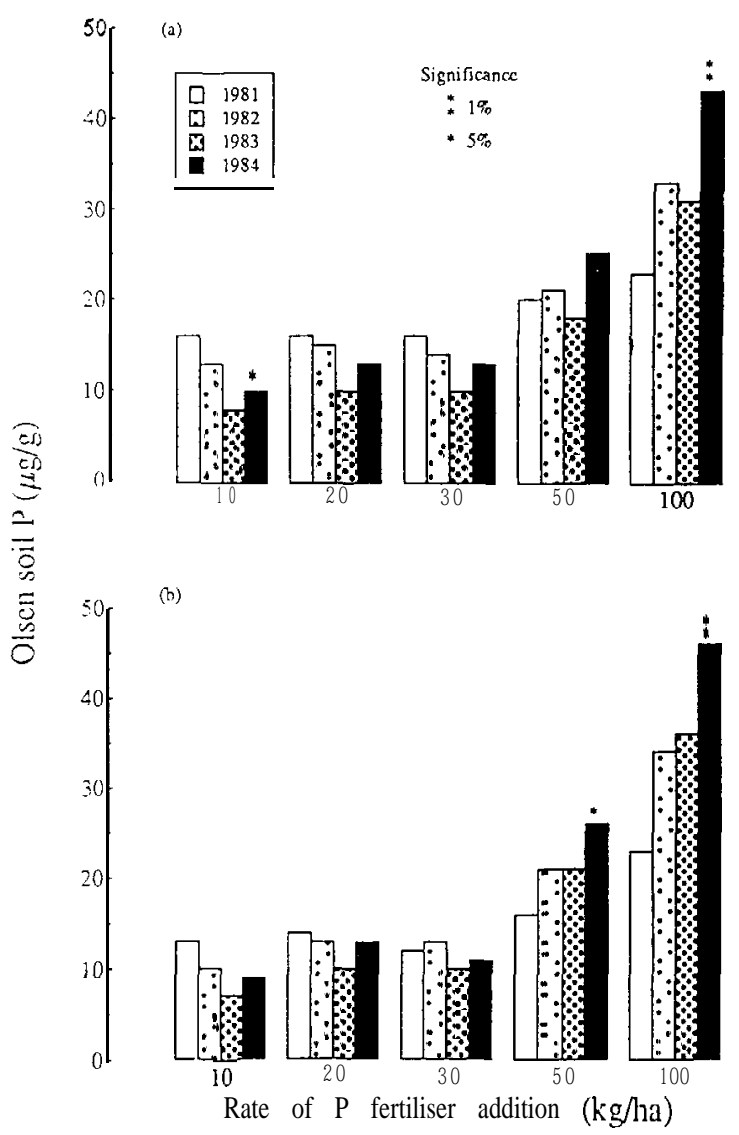

Figure 3 Effect of $\mathrm{P}$ fertiliser rate and time on Olsenextractable $\mathrm{P}$ on (a) easy slopes and (b) steep slopes. Data presented are from all paddocks.

As inorganic $\mathrm{P}$ becomes depleted, Olsen $\mathrm{P}$ decreases, most noticeably where initial levels were high and where dung $\mathrm{P}$ returns are insufficient to meet high plant $\mathrm{P}$ demands (i.e., easy slopes). It will be difficult to detect where moderate rates of $\mathrm{P}$ fertiliser have been added in the past because Olsen $\mathrm{P}$ status is generally medium to low and soil variability in hill country obscures small changes. A decrease in Olsen $\mathrm{P}$ will be associated with a decrease in herbage $\mathrm{P}$ uptake which will result in

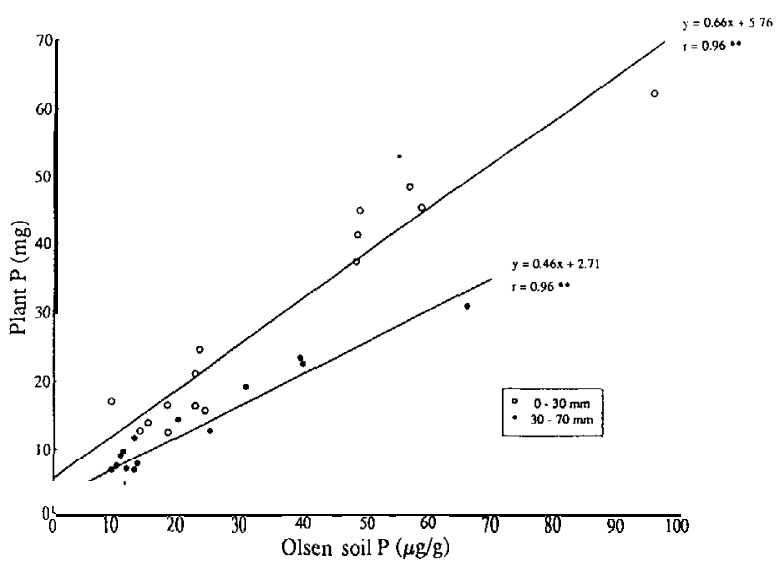

Figure 4 Effect of sampling depth on the relationship between plant $\mathrm{P}$ uptake (mg) and initial levels of Olsenextractable $P$

less $\mathrm{P}$ being transferred in dung to campsites, and more time for dung degradation. $\mathrm{P}$ will cycle more slowly, and pastures will gradually produce less.

Increasing productivity from this stage will require not only using $\mathrm{P}$ fertiliser, but also time for macro- and micro-organisms, plus high producing plant species to regenerate.

\section{REFERENCES}

Bruce, J.L. 1976. Soil map of part of Raglan County, South Auckland, New Zealand. Soil Bureau Map 100.

Gillingham, A.G.; Bircham, J.S. 1985. Soil moisture monitoring and modelling on steep hill country. pp 218-229. In Proceedings of a Seminar on Soil Dynamics and Land Use. I.B. Campbell (ed.).

Gillingham, A.G.; Richardson, S. Power, I. 1989. The long term effects of withholding phosphate application on North Island hill country. 1. Whatawhata Research Centre. Proceedings of the NZ Grassland Association 51:

Lambert, M.G.; Clark, D.A.; Mackay, A.D. 1989. The long term effects of withholding phosphate application on North Island hill country. III. Ballantrae. Proceedings of the NZ Grassland Association 51:

O'Connor, M.B.; Shannon, P.W.; Gillingham, A.G. 1985. The effects of withholding fertiliser on pastoral production on hill country. Proceedings of the New Zealand Fertiliser Manufacturers' Research Association Technical Conference 20: 260-273.

O'Connor, M.B.; Smart, C.E.; Ledgard, SF. 1989. The long term effects of withholding phosphate application on North Island hill country. II. Te Kuiti. Proceedings of the NZ Grassland Association 51:

Olsen, S.R.; Cole, C.V.; Watanabe, F.S.; Dean, L.A. 1954 Estimation of available phosphorus in soils by extraction with sodium bicarbonate. United States Department of Agn'culture Circular 939. 19 pp.

Rowatth J.S. 1987. Phosphate cycling in grazed hill-country pasture. PhD Thesis. Soil Science, Massey University, New Zealand. 349 pp. 
Rowarth, J.S.; Tillman, R.W.; Gillingham, A.G.; Syers, J.K. 1985. Release of phosphorus from sheep faeces on grazed, hill country "passtures. NZ Journal of Agricultural Beseareh 28:497-504

Rowarth, JJ.S.:; Gillingham, A.R. ., Tillman, R.W.; Syers, J.K. 1988. Effect of season amd ffertiliser rate on phonotiporasconnechtrations iim opasture and sheep faeces

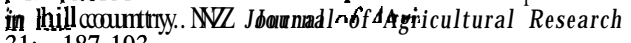
31: $187-193$.

Twine, J.R. Williams, C.H 1971. The determination of phosphorus in kjeldahl digests of plant material by automatic analysis. Communications in Soil Science and Plant Analvsis 2:485-499.

Walker, T.W.; Adams, A.F.R. 1958. Studies on soil organic matter: I. Influence of phosphorus content of parent materials on accumulations of carbon, nitrogen, sulphur and organic phosphorus in grassland soils. Soil Science 85: 307-3 18 .

White, E. 1960. The distribution and subsequent disappearance of sheep dung on Pennine moorland. Journal of Animal Ecology 29:243-250. 